\title{
DRIVERS OF E-GOVERNMENT MATURITY IN TWO DEVELOPING REGIONS: FOCUS ON LATIN AMERICA AND SUB-SAHARAN AFRICA
}

\author{
Princely Ifinedo
}

Cape Breton University, Nova Scotia, Canada

\begin{abstract}
This research focuses on the drivers of e-government (E-gov) maturity in two comparable developing regions of the world i.e. Latin America and Sub-Saharan Africa (LA\&SSA). E-gov maturity refers to the growth levels in a country's online services and its citizens' online participation in governance. To date, few researchers have focused on the drivers of E-gov maturity in LA\&SSA. Given the challenges faced by LA\&SSA with regard to the implementations and deployment of technological innovations including E-gov, research such as this current one is needed to enrich insight in such contexts. Building on a prior framework and the modernization theory (MT), the impacts of macro-environmental factors of political, economic, social, and technological dimensions on E-gov maturity in LA\&SSA are examined. A longitudinal data i.e. a 5-year panel data consisting of 160 observations or data points was used for analysis in conjunction with the structural equation modeling (SEM) technique. Such factors as human capital development, technological infrastructure, and rule of law were found to have positive impacts on E-gov maturity in LA\&SSA. To a large extent, national wealth served as an enabler in the proposed research conceptualization and not as a direct driver of E-gov maturity. The implications of the study's findings for research and policy making are discussed and future research areas noted.
\end{abstract}

Keywords: Electronic government (E-gov); E-gov maturity; Latin America; Sub-Saharan Africa; Panel data; Developing countries; Structural equation modeling

\section{INTRODUCTION}

Electronic government (E-gov) is a transformative, technological innovation of the $21^{\text {st }}$ century that pursues citizen's satisfaction through the use of information and communication technologies (ICT) such as the Internet and the Web (Fountain, 2001; West, 2004; InfoDev, 2004; Ifinedo, 2011). E-gov presents citizens with improved access to government information and services. With better services and greater access,

Manuscript first received/Recebido em 12/09/2011 Manuscript accepted/Aprovado em: 20/03/2012

Address for correspondence / Endereço para correspondência

Princely Ifinedo - Dept. of Financial \& Information Management -Cape Breton University - P. O. Box 5300, Sydney, Nova Scotia, B1P 6L2, Canada Phone: 1902563 1227-Email: princely_ifinedo@cbu.ca; ifinedo@yahoo.com - 
more productive relationships between citizens and governments are created and citizen's attitudes towards governance are positively altered (Fountain, 2001; West, 2004; Wong \& Welch, 2004). For instance, greater levels of participation, transparency, empowerment, and enhanced two-way communication between citizens and their governments are positive fall-outs of E-gov initiatives (Bertort et al., 2001; BoyerWright et al., 2008; UN Public Administration Programme, 2010).

It comes as no surprise that E-gov is accepted as a useful, modern tool for providing quality service to citizens and businesses (UN Public Administration Programme, 2010), reducing corruption and increasing transparency (Bertort et al., 2001; Cho \& Choi, 2004), and increasing democratization (Katchanovski \& La Porte, 2005; Ifinedo and Singh, 2011). In recognition of the growing interest in the area, researchers from across differing academic disciplines have started to examine the factors influencing E-gov diffusion and growth globally (Azad et al, 2010; Moon, 2002; Siau \& Long, 2006; Singh et al., 2007; Wong \& Welch, 2004; West, 2004).

Empirical evidence from both academic research (Azad et al., 2010; West, 2007; Ifinedo \& Singh, 2011) and international agencies' reports (InfoDev, 2004; Accenture, 2001; UN Public Administration Programme, 2010) indicated that emerging economies and developing countries in Latin America and Sub-Saharan Africa (LA\&SSA) lag behind advanced countries in the deployment and use of E-gov. Indeed, Azad et al. (2010, p. 88) citing Rodrik (2003) commented that "the recent challenges of implementing sustainable reforms [including those related to E-gov] in developing and transition economies have proved insurmountable and are largely attributed to weak and or non-existent" environmental factors or considerations pervading such contexts. Similarly, Gebremichael and Jackson (2006) reflected on the myriads of challenges facing developing countries that are unable to harness the power of ICT for development by citing a lack of economic resources, governmental censorship and control, and a lack of infrastructure as some of the main reasons why countries in emerging societies lag behind the industrialized West.

Against the backdrop of the challenges facing citizens and governments in LA\&SSA, researchers have called for more attention to the paid to the progress of Egov in such regions of the world (Campos \& Nugent, 1999; Boyer-Wright \& Kotterman, 2008; Chen et al., 2006; Gebremichael \& Jackson, 2006; Schuppan, 2009). This current study is motivated, in part, by such attention. It is hoped that by concentrating on E-gov maturity - an aspect that has not received much attention in LA\&SSA- useful insights will emerge to enrich our understanding of E-gov progress in such parts of the world, over time.

With respect to the discourse of E-gov maturity around the world, this current research complements the study by Singh et al. (2007) that investigated a similar theme globally by including the effects of political, economic, social, and technological underpinnings on E-gov maturity. Nonetheless, this present research differs from Singh et al.'s work in three ways: a) this study focuses on solely on LA\&SSA for reasons already espoused; b) it underscores the pertinence of such factors as rule of law and transparency levels, which were not considered in their study, c) this effort also seeks to increase the body of knowledge with regard to the mediating influence of the factors under focus. In other words, this research does more than examining the direct impacts of selected factors on the dependent variable as is usually the case in prior studies (Kovačić, 2005; Moon et al., 2005). Further, this current study complements the efforts 
Drivers of E-government Maturity in Two Developing Regions: Focus on Latin America and SubSaharan Africa

of Ifinedo and Singh (2011) who investigated a comparable theme in another region of the world: the transition economies of Central and Eastern Europe.

To guide this discourse, the modernization theory (MT) and the political, economic, social, and technological (PEST) analysis framework will be employed to provide the necessary conceptual underpinning for the study. Publicly available data from reliable sources such as the World Bank and the United Nations over a 5-year period will be used for data analysis.

\section{LITERATURE REVIEW}

A few researchers have discussed E-gov issues in LA\&SSA. For instance, Lau et al. (2008) used a conceptual framework to examine the adoption and development of Egov services in the three Latin American countries: Argentina, Brazil, and Mexico. The study by Campos and Nugent (1999) assessed the development performance and governance institutions in LA and elsewhere. Schuppan (2009) used case studies of three African countries i.e. Ghana, Uganda, and Kenya to discuss the impacts of institutional, cultural, and administrative reforms on E-gov projects in SSA. None of the foregoing studies focused on E-gov maturity, per se.

Research studies that focused on E-gov maturity in LA\&SSA are rare. The one study that did, i.e. the research by Singh et al., 2007) used data from differing regions of the world, including LA\&SSA. Researchers such as Campos and Nugget (1999), Lau et al. (2008), and Ifinedo and Davidrajuh (2005) have suggested that more relevant information can emerge when the views of countries from comparable regions of the world are studied. As countries in LA\&SSA face comparable challenges with regard to accepting and implementing technological innovations, including E-gov (Bertort et al., 2001; Azad et al., 2010; Moon et al., 2005; Siau \& Long, 2006), a focus on such emerging parts of the world is welcoming to the extant E-gov literature.

\section{Conceptual background}

The modernization theory (MT) (McClelland, 1967; Barker, 2005) is relevant to this study as it seeks to identify pertinent macro-environmental variables that impact social change and development of societies. The theory has several facets including political enlightenment, secularization, economic growth, technological progress, inter alia. For the purposes of this study, emphasis will be placed on its aspect that addresses technological advancement across societies (McClelland, 1967; Goldthorpe et al., 1968). Technological innovations, i.e. E-gov serve as a major source of social change and progress (Goldthorpe et al., 1968; Barker, 2005). Accordingly, McClelland's (1967) perspective on the MT is appropriate in providing a conceptual underpinning to this present research. McClelland asserted that modernization cannot happen unless a given society has a pool of requisite factors such as human resource, and political capital, among others. He also maintained that some societies were more advanced than others because of such prevailing contextual factors.

It has been accepted that relatively modernized societies have a higher tendency to adopt, use and benefit from emerging technologies and services than societies that are yet to reach such levels of sophistication (Goldthorpe et al., 1968; Barker, 2005). Given 
that E-gov is an innovative, modern tool for societal development and progress, countries including those in LA\&SSA with the needed macro-environmental resources will be better poised to fully use E-gov to serve and engage their citizens and other stakeholders meaningfully. In contrast, where such resources are lacking or insufficient, the accomplishment of such countries' governments are often limited to trivial benefits that characterize initial phases of such E-gov engagements (Layne \& Lee, 2001; Norris, 2001; UN Public Administration Programme, 2010; Singh et al., 2007; Azad et al., 2010).

To complement the MT, the political, economic, social, and technological (PEST) analysis framework (Byars, 1991; Johnson \& Scholes, 1993), which is essentially business management schema, will be used. The PEST is a tool or framework that organizations use to scan macro-environmental factors with the hope of improving their strategic decision making processes. The framework can be extended to trans-national analysis as well. In fact, others researchers have implicitly drew from the PEST analysis framework in their investigation of the impacts of socio-economic, political, and technological factors on E-gov development across countries (Katchanovski \& La Porte, 2005; Azad et al., 2010; Kovačić, 2005; Singh et al., 2007; Moon et al., 2005). Importantly, Singh et al. (2007) proposed a framework, which informed this present study's research model (Figure 1). Apparently, elements in the PEST analysis framework have been represented in their framework and in the one presented herein. Of note, the item related to government efficiency used in the Singh et al.'s conceptualization was replaced by the political factor of rule of law as government efficiency yielded an inconclusive result in Singh et al.'s research. This study's research framework also highlights the mediating influence of the other factors on E-gov maturity.

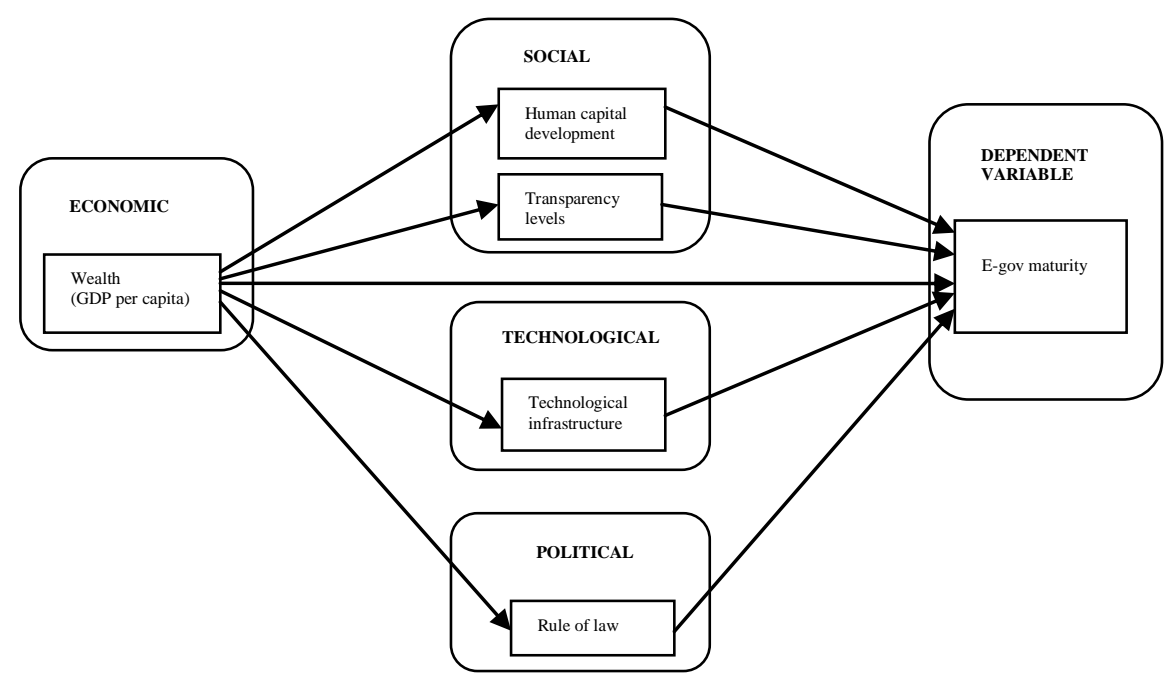

Figure 1. The research model

The relevance of each of the macro-environmental factors are discussed as follows: several prior studies have shown that political factors matter in the development and diffusion of E-gov efforts especially in LA\&SSA (Azad et al., 2010; Chen et al., 2006; Srivastava \& Teo, 2008; Wong \& Welch, 2004). Also, economic 
Drivers of E-government Maturity in Two Developing Regions: Focus on Latin America and SubSaharan Africa

consideration is widely accepted as a major hindrance to E-gov growth globally (Moon et al., 2005; Ifinedo \& Davidrajuh, 2005; Siau \& Long, 2006; Singh et al., 2007). As well, social factors related to inadequate human capital resource, low educational attainment, and corruption/transparency levels have been shown to hamper E-gov growth around the world (Azad et al., 2010; Kovačić, 2005; Moon, 2002; Moon et al., 2005; Singh et al., 2007; Wong \& Welch, 2004). Findings in Moon et al. (2005) and UN Public Administration Programme (2010) showed that poor or inadequate technological infrastructure such as telecommunication networks hinder E-gov diffusion. Admittedly, other macro-environmental factors such as national cultural values and norms could be incorporated into this discourse; however, the selected items were considered adequate for purposes of this preliminary study; moreover, the factors were also included because of their noted importance in prior studies.

\section{The concept of E-government maturity}

According to researchers (Galliers \& Sutherland, 1991; Layne \& Lee, 2001; West, 2007), the concept of "maturity" denotes the state of a given level in a continuous process. It signifies a stage of growth from lower to higher stages or phases in a process. In this research, E-gov maturity refers to the level of progress made by a country regarding its development and the sophistication of the features present on its government websites (West, 2007). E-gov maturity as used by Srivastava and Teo, (2008) combined E-gov development and e-participation measures; the former captures the degree to which governments' websites that have incorporated advanced features capable of providing more efficient, participatory services to their citizens and other stakeholders. The latter assesses the capacity and the willingness of the state to encourage the participation of its citizens in decision-making and the willingness of the citizen to do so.

Thus, countries with high-end features in their web sites are generally seen to occupy higher stages in the growth model. The literature indicates that prior E-gov maturity researchers and international bodies have proposed conceptually similar E-gov maturity models (Layne \& Lee, 2001; Srivastava \& Teo, 2008). However, this current research uses the UN's E-gov framework (UN Public Administration Programme, 2010) as the other E-gov maturity models do not readily provide comparative, global empirical data.

\section{Hypotheses Development}

In general, wealthier nations tend to have higher levels of human capital resource (UN Public Administration Programme, 2010; World Bank, 2011). In tune with the dictates of the MT such economically endowed countries tend to be in the forefront of enlightening their population and providing various opportunities for human capital development needed to facilitate social change and progress (Goldthorpe et al., 1968; Barker, 2005). Thus, it is to be expected that where relative wealth exists in LA\&SSA, there will be a corresponding high level of human capital development. It is therefore predicted that:

H1: In the context of LA\&SSA, wealth will be positively related to human capital development.

Prior research has shown that the diffusion of innovative technologies is significantly influenced by the availability of wealth (as assessed by GDP per capita) (Caselli \& Coleman, 2001; Norris, 2001, Ifinedo \& Davidrajuh, 2005; Moon et al., 
2005; Singh et al., 2007; WEF, 2011). Indeed, more affluent countries with better financial resources than counterparts lacking in such often make more progress regarding the types and scope of quality features and services provided or seen on their government websites (Singh et al., 2007; West, 2007; Ifinedo, 2011). Consistent with the MT, economically endowed countries in LA\&SSA are more likely to be able to procure the necessary technical equipment and infrastructure required to develop and support E-gov initiatives (North, 1990; Norris, 2001; Singh et al., 2007). Likewise, the tenets in the MT imply that wealthier societies are more likely to be open and uphold free enterprise (Goldthorpe et al., 1968; McClelland, 1967). Empirical data indicates the existence of a positive relationship between the availability of economic endowments and the perceptions of transparency levels across countries (McClelland, 1967; Transparency International, 2010; WEF, 2011). It is predicted that:

$\mathrm{H} 2$ : In the context of LA\&SSA, wealth will be positively related to E-gov maturity.

H3: In the context of LA\&SSA, wealth will be positively related to transparency levels.

Global data suggests that wealthier countries are far more likely to be able to commit resources to enhancing their technological infrastructure than relatively poorer nations (Torres et al., 2005; WEF, 2011). McClelland (1967) and Goldthorpe et al. (1968) also observed that more affluent countries tend to be more effective in their use of technological innovations to engender social change compared to relatively poorer nations' capabilities in such areas. Along the same line of reasoning, proponents of the MT, other academic researchers, and international agencies have found an association between the economic well-being of nations and their attitudes toward the national governance variable of rule of law (InfoDev, 2004; Accenture, 2001; North, 1999; West, 2007). That is, the wealthier a country is, the more likely it is for its rule of law to be conducive for governance and business (Norris, 2001; Shih et al., 2005). It is predicted that:

H4: In the context of LA\&SSA, wealth will be positively related to the availability of technological infrastructure.

H5: In the context of LA\&SSA, wealth will be positively related to favorable rule of law climate.

Low level of educational attainment and illiteracy negatively impacts social change (Barker, 2005) and the growth of an information society (Norris, 2001; Caselli \& Coleman, 2001; WEF, 2011). The UN human capital index, which encompasses average years of schooling (across the three main levels) in populations, as well as literacy rates, captures this social measure across countries. Moon et al. (2005), Singh et al. (2007), and Ifinedo (2011) found the human capital index to be positively related to E-gov maturity across countries. It can be argued that the capability to utilize innovation such as E-gov for socio-economic development purposes is relatively high for countries with quality human capital resource. It is safe to believe that top-end features on government websites will be appreciated, demanded, and supported by individuals in countries with a pool of quality human capital compared to where such are lacking. It is predicted that:

H6: In the context of LA\&SSA, human capital development will be positively related to E-gov maturity. 
Drivers of E-government Maturity in Two Developing Regions: Focus on Latin America and SubSaharan Africa

Corruption is a social problem (Maingot, 1994). Transparency International (2010) publishes the Corruption Perceptions Index (CPI) of countries around the world by comparing the degree "to which corruption is perceived to exist among public officials and politicians." Corruption and a lack of transparency denote abuses related to a lack of openness and abuse of entrusted power. Broadly speaking, more open societies with a more enlightened public sector governance structure affording more transparency to government operations would appreciate a need to take their E-gov schemes to levels where citizen participation, engagement and empowerment are encouraged. Research has shown that corruption/transparency perceptions are significantly associated with Egov progress and diffusion (Azad et al., 2010; Bertort et al., 2005; Cho \& Choi, 2004; Kovačić, 2005). It is predicted that:

H7: In the context of LA\&SSA, transparency levels (i.e. low corruption perceptions) will be positively related to E-gov maturity.

Previous research studies indicated that innovative technologies spread where enabling technological infrastructure are present (Singh et al., 2007; Norris, 2001; Moon et al., 2005). Indeed, Moon et al. (2005) found that the more technologically advanced (i.e. a higher level of technological infrastructure) a country is, the more likely it is for the country to advance its E-gov projects and agenda. Indeed, Singh et al. (2007), Azad et al. (2010), Ifinedo (2011), and Ifinedo \& Singh (2011) found that the availability of technological infrastructure positively influences E-gov maturity and growth across nations. It is predicted that:

H8: In the context of LA\&SSA, the availability of technological infrastructure will be positively related to E-gov maturity.

Rule of law refers to the sound political institutions, impartial systems, and legal protection of property rights in a country (Shih et al., 2005). It impacts the diffusion of e-commerce and E-gov (Oxley \& Yeung, 2001; Welch \& Wong, 2004; Katchanovski \& La Porte, 2005; Ifinedo, 2011). Some of the reasons as to why countries in LA\&SSA lag behind advanced countries in technological innovations such as E-gov have been attributed to weak and or non-existent national governance institution factors pervading the developing world (Azad et al., 2010; Gebremichael \& Jackson, 2006; Schuppan, 2007). Thus, countries in LA\&SSA with favorable rule of law climates will have little or no problems in instituting advanced features that facilitate citizen participation and empowerment in governance. The same may not be true where serious rule of law issues exist (Katchanovski \& La Porte, 2005). Welch and Wong (2004) and Kovačić (2005) indicated that the authorities of countries with poorer "rule of law" may have little or no interest in providing advanced features on their websites that would encourage citizen engagement and empowerment as such enhancement may be deemed to engender dissent. It is predicted that:

H9: In the context of LA\&SSA, rule of law will be positively related to E-gov maturity. 


\section{RESEARCH METHODOLOGY}

\section{Data sources and measures}

The research data was obtained from reputable world organizations such as the United Nations and the World Bank. Prior comparable studies have used data from such sources (e.g. (Azad et al., 2007; Katchanovski \& La Porte, 2005; Kovačić, 2005; Singh et al., 2007; Siau \& Long, 2006; Ifinedo, 2011). Each country's technological infrastructure level was assessed using a weighted index comprised of Internet users $/ 1000$ persons, PCs/1000 persons, telephone lines/1000 persons, online populations, mobile phones/100 persons, and TVs/1000 persons (UN Public Administration Programme). The human capital index was obtained from the UN Public Administration Programme (2010); it is derived from measures related to the educational attainment and literacy levels across countries. The rule of law variable was obtained from Kauffman et al. (2009). These researchers composed their data from qualitative and quantitative sources. The rule of law scores ranged from +2.5 and -2.5 with higher scores indicating better values.

The data for the transparency levels variable came from the Transparency International (2010); the scores ranged from 0 to 10 with higher numbers indicating less corruption and more transparent societies. The GDP per capita was obtained from the World Bank's Development Index (World Bank, 2011). The GDP per capita variable was transformed and normalized with a logarithmic function. For the dependent variable, two index scores i.e. the online services and E-participation indices from the UN Public Administration Programme (2010) were aggregated (please see Singh et al., 2007). In line with the objectives of this study, countries from various parts of Latin America and Sub-Saharan Africa as categorized in the UN Public Administration Programme's (2010) E-gov survey and the World Bank were chosen randomly for illustration purposes. In order to have a fair representation of countries from the two regions, E-gov scores at all levels i.e. above and below scores for the region's average as well as scores close to the average were considered from the UN Public Administration Programme's data source. Table 1 shows the selected countries in LA\&SSA used in the research. 
Drivers of E-government Maturity in Two Developing Regions: Focus on Latin America and SubSaharan Africa

Table 1. Selected countries/regions in the study

\begin{tabular}{|l|l|}
\hline Latin America & Sub-Saharan Africa \\
\hline Cuba & Mauritius \\
\hline Chile & Kenya \\
\hline Argentina & Zambia \\
\hline Ecuador & South Africa \\
\hline Peru & Botswana \\
\hline Brazil & Nigeria \\
\hline Uruguay & Ghana \\
\hline Mexico & Cameroon \\
\hline Colombia & Cape Verde \\
\hline Bolivia & Senegal \\
\hline Paraguay & Lesotho \\
\hline Venezuela & Angola \\
\hline Costa Rica & Chad \\
\hline Honduras & Cote d'Ivoire \\
\hline Nicaragua & Gabon \\
\hline Guatemala & Ethiopia \\
\hline
\end{tabular}

\section{Procedure and Method}

The data consists of items collected over a 5-year data period (2003-5, 2008, and 2010) in a span of 7 years. Essentially, the data used in this study is a panel data (also known as longitudinal or cross-sectional time-series data). This procedure is appropriate in capturing the development of E-gov maturity in the selected countries/regions, over time. The advantage in using a panel data lies in the fact that it accommodates variations regarding changes in used variables; a single year study (cross-sectional analysis) may not reflect such changes. The number $(\mathrm{N})$ of observations/points in the data set is 80 for each region and 160 for all the countries in the study. Thus, this study's sample size compares with similar studies in the literature (Azad et al., 2010; Wong \& Welch, 2004).

Furthermore, a panel data takes the fixed-effects (FE) into consideration. With $\mathrm{FE}$, it is assumed that each independent variable has its own individual characteristics that may or may not influence the dependent variable. Notably, FE removes the effect of those time-invariant characteristics from the predictor variables so that the predictors' net effect can be assessed. Thus, the pooled time series data enables precise estimates and test statistics with more power in the regression to be obtained. Having said that, this study's analysis will use the structural equation modeling technique, which is similar to the ordinary regression model (Chin, 1998). 


\section{ANALYSIS AND RESULTS}

The Partial Least Squares (PLS) technique of structural equation modeling, which utilizes a principle component-based for estimation, was used for analysis. The approach is suitable for validating predictive models (Chin, 1998). The PLS assesses the psychometric properties of the measurement model, and estimates the parameters of the structural model. The specific tool used was SmartPLS 2.0 (Ringle et al., 2005). The required information related to measurement model (e.g. AVE, composite reliability was not shown as the study's variables have single item). However, the descriptive statistics and inter-correlations among the constructs from the PLS analysis is presented in Table 2; the table's information does not indicate that multicollinearity was a problem for the research.

Table 2. Descriptive statistics and the inter-construct correlations $(\mathrm{N}=160)$

\begin{tabular}{|l|l|l|l|l|l|l|l|l|}
\hline Construct & Mean & S.D. & 1 & 2 & 3 & 4 & 5 & 6 \\
\hline $\begin{array}{l}\text { 1:E-governemnt } \\
\text { maturity }\end{array}$ & 0.22 & 0.18 & 1 & & & & & \\
\hline $\begin{array}{l}\text { 2:Human capital } \\
\text { development }\end{array}$ & 0.96 & 0.64 & 0.50 & 1 & & & & \\
\hline 3: Rule of law & 0.26 & 0.18 & -0.32 & 0.01 & 1 & & & \\
\hline $\begin{array}{l}\text { 4:Technological } \\
\text { infrastructure }\end{array}$ & 0.28 & 0.08 & 0.68 & 0.61 & -0.24 & 1 & & \\
\hline $\begin{array}{l}\text { 5:Transparency } \\
\text { levels }\end{array}$ & 3.18 & 1.52 & 0.40 & 0.20 & -0.35 & 0.59 & 1 & \\
\hline $\begin{array}{l}\text { 6: Wealth (GDP } \\
\text { per capita) } \\
\text { \$USD }\end{array}$ & 5553.56 & 3862.63 & 0.53 & 0.31 & -0.34 & 0.70 & 0.58 & 1 \\
\hline
\end{tabular}

S.D. $=$ Standard deviations

In the structural model, information related to path coefficients $(\beta)$ and the squared $\mathrm{R}\left(\mathrm{R}^{2}\right)$ are made available. The strength of the relationship is indicated by the $\beta$, which can be interpreted exactly like standardized regression coefficients. The $\mathrm{R}^{2}$ shows the percentage of variance in the model to give an indication of its predictive power. The SmartPLS 2.0 results for the $\beta$ s and the $\mathrm{R}^{2}$ are shown in Figure 2. The path significance levels (t-values) are estimated by the bootstrapping method. 


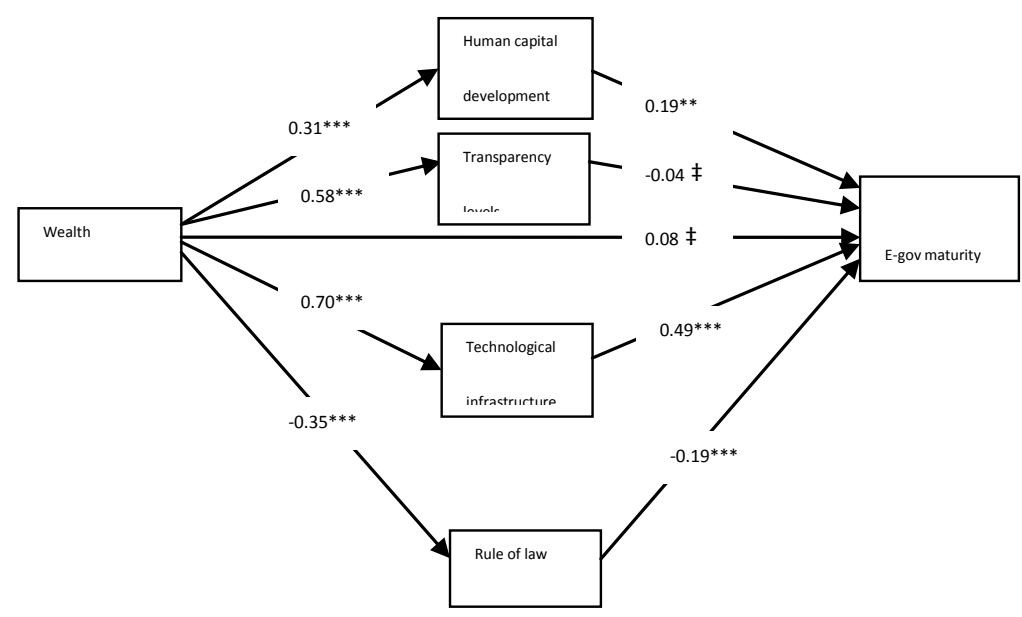

Note: $* *=$ significant at $\mathrm{p}<0.05 ; * * *=$ significant at $\mathrm{p}<0.001 ;+=$ not significant

Figure 2. The paths with results from SmartPLS

The data provided significant support for hypothesis H1, which predicted that in the context of LA\&SSA, wealth would be positively related to human capital development $(\beta=0.31)$. Hypothesis $(\mathrm{H} 2)$ that suggested that wealth of countries in LA\&SSA would be positively related to their E-gov maturity levels, was unsupported by the data $(\beta=0.08)$. The analysis confirmed the prediction indicating that wealth of countries in LA\&SSA would be positively related to their transparency levels $(\beta=$ 0.58 ). The data showed that countries in LA\&SSA with higher levels of wealth tend to have higher technological infrastructure $(\beta=0.70)$ to support hypothesis $H 4$. The result did not provide support for hypothesis H5, which suggested that in the context of LA\&SSA, wealth would be positively related to favorable rule of law climate; however, the data analysis indicated a significant, negative relationship between the two variables $(\beta=-0.35)$.

Hypothesis H6 was strongly supported to affirm the view indicating that in the LA\&SSA region, human capital development was positively related to E-gov maturity $(\beta=0.19)$. Hypothesis $(\mathrm{H} 7)$ indicating that for countries in LA\&SSA, their transparency levels would be positively related to their E-gov maturity levels was unconfirmed by the path significance $(\beta=-0.04)$. Strong support was provided for the prediction made in hypothesis $\mathrm{H} 8$ suggesting that in the context of LA\&SSA, the availability of technological infrastructure would be positively related to E-gov maturity $(\beta=0.49)$. Hypothesis H9 stated that, "in the context of LA\&SSA, rule of law will be positively related to E-gov maturity"; however, the result did not support this prediction as the result indicated a significant, negative relationship between the two factors $(\beta=-0.19)$.

Information related to the variances explained by the study's constructs is presented in Figure 2. It is worth noting that all the research' constructs explained 52\% of the variation in the research model to indicate that the theorized conceptualization has relevance. Specifically, Chin (1998) noted that $\mathrm{R}^{2}$ values of $0.67,0.33$, and 0.19 for the percentage of variance in a model are substantial, moderate and weak, respectively. Thus, the obtained $\mathrm{R}^{2}$ in this study with a value of 0.52 suggests that the percentage of variance in the research model is above moderate levels. 


\section{DISCUSSIONS}

While IS and public administration researchers have provided information regarding the impacts of a variety of macro-environmental factors on the diffusion, growth, and maturity of E-gov globally, the review of the extant literature showed that studies designed to highlight perspectives from LA\&SSA are not well represented. This current research is partly designed to fill this gap in the literature. Discussions related to the unconfirmed hypotheses will be presented first and the supported ones come afterward.

The research model did not provide evidence in support of the positive, direct associations between national wealth and E-gov maturity. Also, the transparency levels variable was not found to be positively related to E-gov maturity in the context of LA\&SSA. Additionally, the data analysis showed that the relationship between wealth and rule of law was negative in nature; the same result was obtained for the relationship between rule of law and E-gov maturity. These unconfirmed hypotheses do not, in any way, affirm that such factors have no bearings on E-gov maturity issues in LA\&SSA and elsewhere. For instance, the lack of support for the relationships between rule of law and E-gov maturity are counterintuitive propositions, which need further investigation.

One plausible reason for the unconfirmed predictions in the research may be due to incomplete and missing data of some of the measures used in the research. Another explanation could be that political factors e.g. government efficiency and rule of law may actually have inverse relationships with E-gov maturity across countries. One could posit that transparency levels may not be conceptually related to E-gov maturity; however, the findings in this aspect of E-gov research appear to be diverse. For example, some researchers (Azad et al., 2010; Kovačić, 2005; Singh et al., 2007; Ifinedo, 2011) have supported the pertinence of transparency/corruption levels on E-gov diffusion and maturity; others (e.g. Ifinedo \& Singh, 2011) have not supported such a viewpoint. However, more studies are needed to debunk or reify insights on the relevance of the foregoing construct on E-gov issues.

It is worth mentioning that evidence suggests that governments in some countries with unfavorable rule of law have made tremendous gains with regard to using E-gov initiatives, including sophisticated features to control their citizens and for general propaganda purposes (Schuppan, 2007; Singh et al., 2007; Katchanovski \& La Porte, 2005). This information could shed some light on the significant, negative results obtained in the research.

With respect to national wealth, global sources of information have shown that some remarkable progress on E-gov diffusion, expansion, and maturity has been recorded in relatively poorer countries around the world (Accenture, 2001; InfoDev, 2004; UN Public Administration Programme, 2010). The foregoing insight and the revelation made in this research to suggest that the availability of wealth, per se, may not be a direct driver of E-gov maturity in LA\&SSA is welcoming and serves to engender our overall understanding of the impact of such a factor. Singh et al. (2007) presented a similar viewpoint in their study. Thus, this current research is indicating that 
wealth matters insofar as it helps to influence the other factors or indicators of E-gov maturity (Ifinedo, 2011; Ifinedo and Singh, 2011).

Regarding the supported hypotheses, the results obtained and the conclusions made hereafter are presented in the context of the data collected. Of note is the fact that this research's conceptualization does not imply causation in the model. That being said, where wealth is sufficiently available, the human capital development of such societies tends to be relatively higher as the data analysis has shown. The data confirmed the notion that economic resources are likely to be vitally important to governments and their citizens in their bids to acquire requisite technological products (e.g. hardware and software) to further enhance E-gov initiatives. As well, wealth and the transparency levels in countries are positively related; prior sociological and E-gov studies have denoted the existence of such a relationship (Maingot, 1994; Cho \& Choi, 2004; Kovačić, 2005).

Consistent with the MT, richer countries in LA\&SSA are more likely to have the capacity to develop their human capital, have an enabling technological capital and engender openness in their contexts; the foregoing resources go a long way in engendering social change and progress as represented, in this instance, by advancement in E-gov initiatives than counterparts lacking in such resources (McClelland, 1967; Goldthorpe et al., 1968; Barker, 2005). The data showed that higher pools of quality human capital resource have positive effects on E-gov maturity; this finding is consistent with the stated hypothesis. In that regard, the result may be indicating that such quality human resource perhaps may have a better understanding of how to deploy and use advanced E-gov features to better serve their well being.

Greater capabilities and knowledge can permit a better understanding and appreciation of advanced technological products like those present in websites with higher-end features. Prior research has shown that human capital development boded well for E-gov expansion (Norris, 2011; Wong \& Welch, 2004; West, 2007). The data is suggesting that countries in LA\&SSA with more technological amenities were the ones that had more favorable E-gov maturity scores. It is reasonable to believe that citizen engagement and empowerment through sophisticated technology-enhanced platforms can only thrive where the necessary, enabling physical infrastructure are available (Norris, 2001; Azad et al., 2010; Moon et al., 2005; West, 2007)

\section{Implications for Research}

This research presents some useful implications for research. First, it has attempted to answer the call for researchers to focus on E-gov development issues in emerging societies of the world, including LA\&SSA so as to deepen our understanding of issues in such contexts. In that light, this endeavor's presentation of perspectives from LA\&SSA is a welcoming contribution to the literature. Second, it contributes to, and seeks to make a case for the applicability of the MT to E-gov research; the results obtained in this study lend support to the tenets in the MT. This research clearly articulates the relevance of the PEST analysis framework for investigating technological innovations across trans-national settings. Future researchers could draw from and expand on the foregoing theoretical underpinnings and concepts in discussing comparable issues.

Third, this study's findings lend credence to views and observations that have tested the impacts of relevant environmental factors i.e. wealth, human capital, technological infrastructure, rule of law, and transparency levels on E-gov diffusion, 
development, and maturity in the literature (e.g. Moon, 2002; Wong \& Welch, 2004; Katchanovski \& La Porte, 2005; Moon et al., 2005; Kovačić, 2005; Singh et al., 2007; West, 2007; Azad et al., 2010; Ifinedo \& Singh, 2011; Ifinedo, 2011). Accordingly, research, in general, benefits from such accumulation of knowledge.

Fourth, previous research on E-gov issues in LA\&SSA has used a single nation or a few countries in their analysis. By using a panel data of 32 countries in LA\&SSA, this current endeavor provides rich and robust insight that a cross-sectional data may not afford. Fifth, strong support for the mediating roles of technological infrastructure and human capital resource on E-gov maturity was established. The role of national wealth as a foundation or an enabler for enhancing progress vis-à-vis E-gov initiatives is underscored. Sixth, as this current research's findings mirror those reported by Ifinedo and Singh (2011) in their investigation of the determinants of E-gov maturity in the transition economies of Central and Eastern Europe, it is postulated that the challenges to E-gov maturity compare in emerging regions of the world. Such insights could inform the development of a "macro-environmental model of E-gov maturity", which other researchers could benefit from as they investigate similar themes in comparable regions of the world.

\section{Implications for practice}

This study also offers implications for policy makers, international agencies, and public administrators. In light of economic resources being conceptualized as the bedrock upon which other relevant factors such as human and technological capitals could impact E-gov maturity, it is necessary for international agencies and policy makers to find ways of assisting countries lacking in such resources in order to improve E-gov initiatives in the regions. Governments in LA\&SSA are alerted to the salient factors that could constitute possible drivers of E-gov progress in their contexts. Accordingly, more attention may be placed on such noted factors to enhance their E-gov advancement.

This research argues that if wealth is properly marshaled toward improving the quality human development as well as procuring required technological infrastructure, it is likely that positive outcomes on the E-gov development front will ensue. Financial support from relevant sources may be called upon to accelerate investments in infrastructural acquisitions that relatively poorer nations may be lacking in order to improve their E-gov capabilities. Policy makers and governments in comparable regions of the world such as South East Asia and elsewhere may benefit from the information provided herein. Against the backdrop of this study's findings, it may be advisable for LA\&SSA's governments that are serious about obtaining favorable E-gov maturity to benchmark their own policies and efforts against counterparts identified by international bodies as having favorable E-gov indicators.

\section{LIMITATIONS AND DIRECTIONS FOR FUTURE STUDY}

There are some limitations in this research. The study relied on secondary data sources; as such, it is difficult to ascertain with certainty the reliability and validity of items used in composing the various measures. The dependant variable i.e. the E-gov maturity indicator largely used the assessment of efforts on governments' websites; the 
views of citizens are not represented. This might be limiting given that citizens' perceptions and expectations of E-gov initiatives may be dissimilar from those of their governments'. The lack of an internationally recognized 'E-gov maturity' indicator may have its drawbacks. Some of the items we used had missing entries for some of the countries and some data were not up-to-date; these might have negatively impacted the data analysis.

In selecting the countries for the research, the UN Public Administration Programme's (2010) E-gov scores were used to guide the selection. Notwithstanding, selection bias cannot be ruled out. The amount variation in the dependent variable i.e. $52 \%$ explained by the macro-environmental factors suggest that other relevant factors such as cultural norms and values, political actors' actions, citizen awareness and resistance not included in this study could be relevant for the study. Future studies should endeavor to work with a more comprehensive framework that includes such factors. This study was limited to a five-year observation period; it is advised that as more data become available, a much longer observation period should be considered to enhance insight. More information as to the pertinence of political factors in E-gov discourse is needed. Other researchers could replicate this study in other comparable contexts such as the Middle East or South Asia. Accumulated body of knowledge on the possible determinants or drivers E-gov maturity is welcoming to theory development and consolidation.

\section{CONCLUDING REMARKS}

This research utilized perspectives from the modernization theory (MT) and PEST analysis to guide the discourse of the factors impacting E-gov maturity in LA\&SSA. This study used a panel data of 32 countries in the regions to provide insight. The analyses showed that that resources (e.g. wealth, human capital, and the availability of technological infrastructure) do matter in accelerating a country's the ability and willingness to advance its E-gov projects with features that promote citizens' participation and engagements. The mediating roles of human capital and technological infrastructure are underscored in the research model. In general, the supported predictions in the research are congruent with findings in similar prior studies and serves to enhance our understanding of the factors that could be perpetuating the slow progress of E-gov initiatives across LA\&SSA and other comparable parts of the world. The unconfirmed hypotheses open up an opportunity for further investigations. The relevance of the study's findings to researchers, policy makers, and governments are presented. The replication of this endeavor in other emerging societies of the world is advised; such an exercise will improve knowledge related to the factors impacting Egov progress (or lack thereof) in such contexts.

\section{Acknowledgement}

The author is grateful to C. M. Ringle, S. Wende, and A.Will for the use of their software, SmartPLS 2.0. The author is grateful for the constructive comments and suggestions received from two anonymous reviewers of an earlier draft of this paper. 


\section{REFERENCES}

Accenture (2001). eGovernment Leadership Rhetoric vs Reality - Closing the Gap. Retrieved May 2, 2009 from http://www.epractice.eu/files/media/media_846.pdf

Azad, B., Faraj, S. \& Goh J.F. (2010). What Shapes Global Diffusion of e-Government: Comparing the Influence of National Governance Institutions, Journal of Global Information Management, 18, 2, 85-104.

Barker, C. (2005). Cultural Studies: Theory and Practice, London, Sage.

Bertort, J.C., Jaeger, J.T. \& Grimes, J.M. (2001). Using ICTs to Create a Culture of Transparency: E-government and Social Media as Openness and Anti-corruption Tools for Societies, Government Information Quarterly, 27, 264-271.

Boyer-Wright, K.M. \& Kotterman, J.E. (2008). High Level Factors Affecting Availability of Online Government Services Worldwide, Electronic Government: An International Journal, 5, 4, 375-389.

Byars, L. (1991) Strategic Management, Formulation and Implementation - Concepts and Cases, New York, HarperCollins.

Campos, N.F. \& Nugent, J.B. (1999). Development Performance and the Institutions of Governance: Evidence from East Asia and Latin America, World Development, 27, 3, 439-452.

Caselli, F. \& Coleman, W. (2001). Cross-country Technology Diffusion: The Case of Computers, American Economic Review, 91, 2, 328-335.

Chen, Y. N., Chen, H. M., Huang, W. \& Ching, R.K.H. (2006). E-Government Strategies in Developed and Developing Countries: An Implementation Framework and Case Study, Journal of Global Information Management, 14, 1, 23-46.

Chin, W. (1998). Issues and Opinion on Structural Equation Modeling, MIS Quarterly, 22(1), vii-xvi.

Cho, Y. H., \& Choi, B. (2004). E-government to Combat Corruption: The Case of Seoul Metropolitan Government, International Journal of Public Administration, 27, 10, 719735 .

Fountain, J.E. (2001). Building the Virtual State: Information Technology and Institutional Change. Washington, D.C., The Brookings Institution.

Galliers, R. D. \& Sutherland, A. R. (1991). Information Systems Management and Strategy Formulation: The Stages of Growth Model Revisited, Journal of Information Systems, 1, 2, 89-114.

Gebremichael, M., \& Jackson, J. (2006). Bridging the Gap in Sub-Saharan Africa: A Holistic Look at Information Poverty and the Region's Digital Divide, Government Information Quarterly, 23, 267-280.

Goldthorpe, J. H., Lockwood, D., Bechhofer, F. and Platt, J. (1968). The Affluent

Worker: Industrial Attitudes and Behaviour, Cambridge, the UK, Cambridge University Press.

Ifinedo, P. \& Davidrajuh, R. (2005). Digital Divide in Europe: Assessing and Comparing the E-readiness of a Developed and an Emerging Economy in the Nordic Region, Electronic Government: An International Journal, 2, 2, 111 - 133. 
Drivers of E-government Maturity in Two Developing Regions: Focus on Latin America and SubSaharan Africa

Ifinedo, P. (2011). Factors Influencing E-government Maturity in Transition Economies and Developing Countries: A Longitudinal Perspective, The DATA BASE for Advances in Information Systems, 42, 4, 98-116.

Ifinedo, P. \& Singh, M. (2011). Determinants of eGovernment Maturity in the Transition Economies of Central and Eastern Europe, Electronic Journal of eGovernment, 9, 2, $166-182$.

InfoDev (Information for Development Programme) (2004). E-government Handbook for Developing Countries. Retrieved May 6, 2006 from http://www.infodev.org

Johnson, G. \& Scholes, K. (1993) Exploring Corporate Strategy - Text and Cases, Hemel Hempstead, Prentice-Hall.

Katchanovski, I. \& La Porte, T. (2005). Cyberdemocracy or Potemkin E-Villages? Electronic Governments in OECD and Post-Communist Countries, International Journal of Public Administration, 28, 7 \& 8, 665-681.

Kaufmann, D., Kraay, A. \& Mastruzzi, M. (2009).Governance Matters VIII. Aggregate and Individual Governance Indicators 1996-2008. Policy Research Working Paper (The World Bank). Retrieved Sept 30, 2010 from http://papers.ssrn.com/sol3/papers.cfm?abstract_id=1424591

Kovačić, Z. (2005). A Brave New eWorld? An Exploratory Analysis of Worldwide eGovernment Readiness, Level of Democracy, Corruption and Globalization, International Journal of Electronic Government Research, 1, 3, 15-32.

Lau, T.Y., Aboulhoson, M., Lin, C. \& Atkin, D.J. (2008). Adoption of E-government in Three Latin American Countries: Argentina, Brazil and Mexico, Telecommunications Policy, 32, 88-100.

Layne, K. \& Lee, J. (2001). Developing Fully Functional e-Government: A Four Stage Model, Government Information Quarterly, 18, 2, 122-136.

Maingot, A. (1994). Confronting Corruption in the Hemisphere: A Sociological Perspective, Journal of InterAmerican Studies and World Affairs, 36, 3, 49-74.

McClelland, D.C. (1967). The Achieving Society, New York, van Nostrand Publishers.

Moon, J.M. (2002). The Evolution of E-government among Municipalities: Rhetoric or Reality? Public Administration Review, 62, 4, 424-433.

Moon, M.J., Welch, E.W. \& Wong, W. (2005). What Drives Global E-governance? An Exploratory Study at a Macro level. In Proceedings of the $38^{\text {th }}$. Hawaii International Conference on System Sciences.

Norris, P. (2001). Digital Divide: Civic Engagement, Information Poverty, and the Internet Worldwide, New York, Cambridge University Press.

North, D. (1990). Institutions, Institutional Change and Economic Performance, Cambridge, Cambridge University Press.

Oxley, J.E. and Yeung, B. (2001). E-commerce Readiness: Institutional Environment and International Competitiveness, Journal of International Business Studies, 32, 4, 705-723.

Ringle, C.M., S. Wende, A. Will (2005). SmartPLS 2.0 (M3) beta, Hamburg: http://www.smartpls.de. 
Rodrik, D. (2003). Institutions, Integration, and Geography: In Search of the Deep Determinants of Economic Growth. In Rodrik, D. (Ed.), Search for Prosperity: Analytic Country Studies on Growth, Princeton, NJ., Princeton University Press.

Schuppan, T. (2009). E-Government in Developing Countries: Experiences from SubSaharan Africa, Government Information Quarterly, 26, 118-127

Shih, C-F., Dedrick, J. \& Kraemer, K. L. (2005). Rule of Law and the International Diffusion of E-commerce, Communications of the ACM, 48, 11, 57-62.

Siau, K. \& Long, Y. (2006). Using Social Development Lenses to Understand EGovernment Development, Journal of Global Information Management, 14, 1, 47-62.

Singh, H., Das, A. \& Joseph, D. (2007). Country-Level Determinants of E-Government Maturity, Communications of the Association for Information Systems, 40, 632-648.

Srivastava, S.C. \& Teo, T.S.H. (2007). E-Government Payoffs: Evidence from CrossCountry Data. Journal of Global Information Management, 15, 4, 20-40.

Srivastava, S.C. \& Teo, T.S.H. (2008). The Relationship between E-Government and National Competitiveness: The Moderating Influence of Environmental Factors, Communications of the AIS, 23, 5, 79-94.

The Heritage Foundation (2010). Index of Economic Freedom. Retrieved October 2, 2010 from http://www.heritage.org/

Torres, L., Pina, V. \& Acerete, B., 2005. E-Government Developments on Delivering Public Services among EU Cities, Government Information Quarterly, 22, 217-238.

Transparency International (2010). Corruption Perceptions index (CPI). Retrieved $\begin{array}{llll}\text { October } & 15, & 2010 & \text { from }\end{array}$ http://www.transparency.org/policy_research/surveys_indices/cpi/2009.

UN Public Administration Programme (2011). United Nations E-Government Global $\begin{array}{lllll}\text { Reports. } & \text { Retrieved } & \text { August } & 12, & 2010\end{array}$ http://www2.unpan.org/egovkb/global_reports/10report.htm.

WEF (World Economic Forum) (2011). The Global Information Technology Report 2009-2010. Retrieved October 6, 2010 from http://www.weforum.org/en/initiatives/gcp/Global\%20Information\%20Technology\%20 Report/index.htm.

West, D. (2007). Global Perspectives on E-Government. Retrieved September 2, 2010 from http://www.umass.edu/digitalcenter/events/pdfs/West_GlobalPerspectives.pdf

West, D.M. (2004). E-government and The Transformation of Service Delivery and Citizen Attitudes, Public Administration Review, 64, 1, 15-27.

Wong, W. \& Welch, E. (2004). Does E-Government Promote Accountability? A Comparative Analysis of Website Openness and Government Accountability, Governance: An International Journal of Policy, Administration, and Institutions, 17, 2, 275-297.

World Bank (2011). Countries \& Regions. Retrieved October 3, 2010 from http://web.worldbank.org/. 